\title{
Value Orientation Analysis on the Educational Philosophy of Tao Xingzhi
}

\author{
Chunli Wang \\ Sanmenxia Polytechnic College, Sanmenxia, Henan, 472000, China
}

\begin{abstract}
There are many factors influencing the development of education in the education work, among which the educational idea determines the overall direction and the teaching method of the education work. Thus, advanced educational philosophy is the indispensable spirit of contemporary education and teaching work. This paper first analyzes the three important contents of Tao Xingzhi's educational philosophy, and then discusses the contemporary value of its educational philosophy.

Keywords: Tao Xingzhi; educational philosophy; value orientation; civic education
\end{abstract}

\section{Introduction}

Born at the end of the 19th century, Tao Xingzhi experienced tremendous social changes. He has been living in the bottom of society. He has been suffering from wars and suffering. He is determined to be a pioneer in changing Chinese backwardness. After several practice and hard struggle, and finally the formation of Tao Xingzhi unique educational philosophy, and guide China for nearly a century since the development of education and teaching reform. Tao Xingzhi's educational philosophy mainly includes the following aspects: (1) He believes that life is education and society is the school (2) advocating self-learning, against the "spoon-fed" teaching; (3) advocacy of civilians teaching ideas, universal access to teaching and learning work, promote the teaching of civilians; Educational value orientation refers to the value orientation of education work, which guides the education work in the right direction. Nowadays, what is the 
contemporary value orientation of Tao Xingzhi's educational philosophy, how to use the educational idea of Tao Xingzhi to deepen our country's education reform and promote the further development of education in China, which is the problem that our educators must attach great importance to, Is also the focus of this paper. This article first elaborated Tao Xingzhi's educational idea, then analyzed its value orientation in the new era according to Tao Xingzhi's educational idea.

\section{Tao Xingzhi's educational philosophy}

Tao Xingzhi is the vanguard of Chinese educational career, his life is committed to the study of educational theory and engaged in teaching practice, his educational philosophy is in the process of learning and practice on the formation of education on social development and human progress significance and function And his educational thoughts have been guiding the reform and development of our country's education. To sum up, Tao Xingzhi's educational philosophy mainly includes the following aspects:

\subsection{Life is education, society is school}

Tao Xingzhi that life is the best education, he opposed to education as life. He said, "Life is education, like putting birds in a forest; education is life, just as a bird is in a cage." Through the literal meaning of this sentence, it is not difficult to understand, Tao Xingzhi that the most important way to cultivate talent is to put it in the social environment, let it integrate into society, everything in life can be used as a teacher to guide students' progress; Otherwise, if the education as life, students can only acquire knowledge from the school, which is like a bird in a cage, there will never be soaring in the blue sky. Life is education, life is changing all the time, giving life a different educational significance, life is everywhere and education is everywhere. The whole human society is a place of life, but also a place of educational work. Society is the school, Tao Xingzhi said: "the village or the whole community as a school." He believes that society is a natural school, its all-encompassing and anyone can learn a lifetime of knowledge base. Schools in the process of running a school, not behind closed doors, we must work with the social and teaching practice linked to the masses to do the school. What kind of life in the community, what life can be learned from what knowledge. Education and life are closely related to life can improve education, while education will counteract the role of life, social transformation, transformation of nature.

\subsection{The Implementation of self-learning, against the "spoon-fed" education}

"Spoon-feeding" education is the Soviet educator Keluo Fu invention, the birth of this education model was cast aside by the Soviet people. But because of Chinese education system is not perfect, so they picked up the failure of Keluo Fu. As the name suggests, the so-called "spoon-fed" education is to impose knowledge to 
students, regardless of whether students can understand, as long as rote to remember the purpose of the line. However, after the examination, will soon forget; for the disadvantages, indoctrination-style education leads to the loss of creativity of students, the understanding of knowledge is only to stay on the surface, without seeking solutions. Tao Xingzhi is extremely opposed to this mode of education, in a speech, he took out from the box prepared prior to the big cock, when the audience is still unknown so when he took out from his pocket a meter Placed on the table, and hold the chicken head, forcing the cock pecked rice, and the cock always eat. So he let his assistant to help break the cock's mouth, the meter will be hard stuffed into, but the cock has always been struggling, that is, do not eat. Finally, Tao Xingzhi the cock on the table, and with the people around far away, and soon the big cock will be self-serving to eat rice. "Tao Xingzhi strongly advocated changing the" spoon-fed "education, advocating self-learning, to stimulate students' potential, which is an important manifestation of its teaching philosophy.

\subsection{The implementation of civic education thinking, universal access to teaching work}

Tao Xingzhi thought that the purpose of civic education is to eradicate illiteracy and to cultivate citizens' civic consciousness. Tao Xingzhi thinks that civic education is a kind of civic education. Improve the cultural quality of the people, not only can increase the national history and culture of our country's identity, strengthen national unity, but also can bring more jobs for each person to enhance their ability to live. Tao Xingzhi that through popular education, universal access to education, so that more people understand the rights, democracy, obligations, the meaning of freedom, enlighten the people's democratic consciousness, raise people's ideology, which is the road towards a democratic republic The key step. As the forerunner of educational popularization, civic education must strive for the greatest effect in the shortest possible time. Tao Xingzhi earlier realized the importance of education to the ordinary people. During this period, Tao Xingzhi's educational thought gradually descended from the "altar", and began to focus the teaching work on the civilian population. However, because at that time Tao Xingzhi did not carry out in-depth analysis of the status quo of Chinese education, as well as civilian education activities by the government officials, senior intellectuals led and civilians education activities are mainly directed against civilians, not fully mobilize civilians to participate in teaching activities Enthusiasm. However, through this experience, Tao Xingzhi accumulated a wealth of teaching experience, Tao Xingzhi although also advocated education to save the nation, but in its implementation of civic education thought, not too much political connotation, pay more attention to is the education of people, which is implemented by Yan Yangchu civilians in the educational thinking of the "self-cultivation rule of the whole world," the idea has a great difference, which is the Tao Yan ideological differences lead to the two great educators One of the main reasons. In general, Tao Xingzhi's civic education concept focuses on the development of civilians, rather than the education needed in the war era. He 
hopes to help the quality of the people through civilian education to help the Chinese nation to keep improving.

\section{The contemporary value orientation of Tao Xingzhi educational philosophy}

Tao Xingzhi is committed to teaching for decades and his educational philosophy for the influence of future generations is extremely far-reaching. Nowadays, Mr. Tao Xingzhi has been away for 67 years, but he put forward such educational concepts as "life is education", "society is school", "civic education", "rural education" and "teaching and doing one" still in the development of Chinese education escort, and now the development of the value orientation of the majority of education are based on Tao Xingzhi's educational philosophy.

\subsection{Practical orientation --- rooted in life, adhere to the teaching practice view that education is inseparable from life and society}

Tao Xingzhi thinks: "The fundamental meaning of education is the change of life. Life is changing at every moment that life does not contain the meaning of education." Therefore, Tao Xingzhi's "life is education", "society is school" And other teaching ideas, fully embodies the characteristics of the school practice teaching. Knowledge comes from life, knowledge changes life. Tao Xingzhi that the students in the school system is only the framework of knowledge, and for the specific content within the framework and experience, students need to fill in their own lives, these teachers can not teach. Different individuals, the perception of life, the understanding of knowledge there is a great difference. Therefore, he advocated that education should be the centre of life, through the practice of life, emphasizing the school education to be closely linked with the community, the teaching work into social life, social and school can not be separated, life and education inseparable, education can not be divorced Practical work, but not with people's normal life contrary. Broaden the field of education, and enhance the openness of education. During his period of rural education, he strictly implemented this educational idea, so that teachers and students around the life of education and teaching activities, teachers and students to work together to jointly build schools, so that students in the social practice process to achieve the hands, The liberation of the brain and mouth, the transformation of the traditional thinking of students, the transformation of students thinking. He said: "Education is not to nurture only canonical nerd, but to cultivate the construction of social talents, and for the cultivation of talent, not to pretend to be false, must be combined with teaching and practice." This is the embryonic form of practice teaching in the new period laid a solid theoretical foundation for the reform of modern education in practice teaching. In today's era, the importance of education is more and more prominent and the traditional theoretical teaching model of student capacity imprisonment has been a serious obstacle to the socio-economic and political development needs. Therefore, the education from the closed to 
open, back to the reality of social life, the correct guide students familiar with life, understanding of society, through the analysis of social life phenomenon, improve students ability to distinguish right from wrong; efforts to build the school, family and social trinity Education system, make full use of social resources, and promote sustainable development of education. The practice of Tao Xingzhi's "life is education", "society is the school", "experimentalism" and other practical teaching ideas.

\subsection{The overall orientation - look at the overall situation, establish a "teaching, learning and do" education holistic view}

Mr. Tao Xingzhi believes that the traditional education focus on mechanical indoctrination, emphasis on imparting knowledge, divorced from practice, the teacher's dominant teaching process, students lack initiative and enthusiasm. In response to this question, Tao Xingzhi put forward the proposition of "teaching, learning and doing one" while referring to "life is education" and "society is school". Its meaning is to teach the method according to the method of learning, learning methods to do according to the method. In the traditional teaching methods, teachers and more to "spoon-fed" type of education-based, will educate children will be instilled in the students, regardless of whether students can understand. Compared to teaching philosophy of "teaching, learning and doing one", this teaching method only "teaches" one-sidedly, and its "teaching" is not effective "teaching", just to finish the work "teach". After his return home, Tao Xingzhi put forward the idea of "teaching students to die, to die teaching, to teach to die; to read dead, to read and to die." Teaching students to learn, but also in school rather than teaching, "Tao Xingzhi strongly opposed to teaching, learning, doing separate teaching methods, advocate teaching, learning, doing together. Emphasizing the teacher to "do" as the basis, while self-learning, while teaching students; students to "do" as the basis, while learning, while practice. Instruct students not only to learn but also to learn. As a teacher, we should be teaching activities throughout the practice, or practice activities throughout the teaching activities, in order to truly achieve their knowledge. The teaching idea of Tao Xingzhi emphasizes "doing" as the centre, emphasizing the combination of theory and practice, to liberate students' and teachers' thoughts, improve teaching efficiency and teaching quality, and stimulate students' learning initiative Has a great role in the education method embodies the unity of knowledge and practice of dialectical unity, Tao Xingzhi "teaching, learning, doing one" teaching philosophy, although it has been for many years, today, is still guiding our education The main idea of the comprehensive development of teaching work.

\subsection{The guide education work must be universal}

Tao Xingzhi was born in the old era of corruption under the rule of government in China and he was born from poor to know how to study hard. Coupled with the era of China is in a war era, Tao Xingzhi the road to school after bumpy. Tao Xingzhi hopes to save China through education, and save the country lies in the general improvement of the quality of the people. In view of this, Tao Xingzhi 
the focus of education to improve the country's vast majority of civilians and the quality of rural farmers. Is the so-called: "strong country is that the people, the people of the strong quality, the quality of the strong from education." China wants to self-improvement, to take the road of a democratic republic, we must do a good job of education, but also to do a good job in education for all. The Central Committee of the CPC Central Committee on the reform of the educational system", "Compulsory Education Law", "Chinese Education Reform and Development Program" and other documents that the basic education is to "improve the quality of the nation" and "improve the quality of the people." "Quality education to improve the quality of the people as the goal", "the essence of quality education is the first for the whole", "to carry out quality education must first have a universal education", issued the document still emphasizes universal education. Balanced development of basic education is the basis for building a harmonious society, education for the construction of a harmonious society is the basic requirement of civilians. The basic direction of the development of education is for the majority of the civilian population, the majority of civilians education, we must carry out education for all, teachers in education and teaching, each student, each educational object should be without exception, be a good education, This is also an important manifestation of Tao Xingzhi's teaching philosophy guiding the value orientation of Chinese educational undertakings.

\section{Conclusion}

As a pioneer of education, Tao Xingzhi has made great contributions to the development of modern education in China. Today, his teaching philosophy is still the main value orientation of education in our country. In the development process of Chinese education, we must refine the educational philosophy of Tao Xingzhi, and combined it with the characteristics of the present era and the current status, in order to deepen the reform of Chinese education and promote the further development of Chinese education.

\section{References}

[1] Yu Huaping, Yang Haiyan. Tao Xing-zhi Innovation of Undergraduate Thesis Model in the View of Educational Philosophy. Journal of Industrial Science and Technology, 55(12), pp.68-70, 2011

[2] Zhang Yemao. Hualian educators practice Tao Xingzhi's educational philosophy - private Hualian University, one of the characteristics of the school implement the "Plan" to promote educators to run school seminar papers, pp.8791, 2013

[3] Chen Jianfeng. Tao-zhi-zhi's Idea of Life Education and Practice of Minors' Ideological and Moral Education. Proceedings of the Symposium on Carrying out the Outline of Plan to Promote the Education of Educators, 12(10), pp. 18- 20, 2012 